Article

\title{
Purification, Characterization and in vitro Anti-Tumor Activity of Proteins from Arca subcrenata Lischke
}

\author{
Liyan Song ${ }^{1,2}$, Shengfang Ren ${ }^{2}$, Rongmin Yu ${ }^{2, *}$, Chunyan Yan ${ }^{2}$, Tingfei Li $^{2}$ and Yu Zhao ${ }^{1, *}$ \\ ${ }^{1}$ College of Pharmaceutical Sciences, Zhejiang University, Hangzhou 310058, P.R. China \\ ${ }^{2}$ College of Pharmacy, Jinan University, Guangzhou 510632, P.R. China
}

* Authors to whom correspondence should be addressed; Tel.: +86-20-85220386; Fax: +86-2085224766; Email: tyrm@jnu.edu.cn (R.M. Yu); and Tel.: +86-571-89002539; Fax: +86-571-89002539; Email: dryuzhao@hotmail.com (Y.Zhao)

Received: 2 February 2008; in revised form:8 April 2008 / Accepted: 26 June 2008 / Published: 10 July 2008

\begin{abstract}
Two purified proteins G-6 and G-4-2 were obtained from Arca subcrenata Lischke using the homogenization, salting-out with ammonium sulfate, ion-exchange chromatography and gel filtration chromatography techniques. The purity of G-6 and G-4-2 was over 96\%, as measured by RP-HPLC. G-6 and G-4-2 were measured by SDS-PAGE and IEF-PAGE to have molecular weights of $8.2 \mathrm{kDa}$ and $16.0 \mathrm{kDa}$, and isoelectric points of 6.6 and 6.1, respectively. The amino acid constituents of G-6 and G-4-2 were also determined. The existence of saccharides in G- 6 was demonstrated by the phenol-sulfuric acid method. G-6 and G-4-2 inhibited the proliferation of human tumor cells in vitro. By MTT assay, the $\mathrm{IC}_{50}$ values of G-4-2 were $22.9 \mu \mathrm{g} / \mathrm{mL}, 46.1 \mu \mathrm{g} / \mathrm{mL}$ and $57.7 \mu \mathrm{g} / \mathrm{mL}$ against Hela, HL-60 and $\mathrm{KB}$ cell lines, respectively, and the $\mathrm{IC}_{50}$ value of G-6 against HL-60 cell line was measured to be $123.2 \mu \mathrm{g} / \mathrm{mL}$.
\end{abstract}

Keywords: Arca subcrenata Lischke; protein; purification; in vitro anti-tumor activity

\section{Introduction}

In recent years, more and more researchers have come to the realization that marine organisms hold immense potential as a source of novel molecules and new anticancer agents. Because of their longer evolutionary history, marine organisms likely possess a greater molecular diversity than do their 
terrestrial counterparts [1-2]. Over the past two decades, a global collaborative effort has been raised that aims at the discovery of novel and clinically useful anti-tumor agents derived from marine organisms [3-7]. According to existing literature, more than ten new experimental anti-tumor agents derived from marine sources have entered clinical trials [8], including bryostatin-1, aplidine, ecteinascidin-743 (ET-743) [2], Kahalalide F [9], as well as derivatives of dolastatin such as TZT-1027 [10] and LU 103793 [11].

Arca subcrenata Lischke is a marine invertebrate that belongs to Arcidae family under Phylum Mollusca, Class Lamellibranchiata. A Chinese Traditional Material, wa leng zi (Concha Arcae), is made from $A$. subcrenata. As a marine mollusk native to the seas around China, A. subcrenata has been utilized in the treatments of tumor, anemia and inflammation for centuries in Chinese Traditional medicine [12]. The concentration of protein and saccharide, proportions of amino acid, ultraviolet spectrum analysis and trace element analysis of $A$. subcrenata have been previously reported [13]. Its hydrolysate was found to possess hypoglycemic activity on mice with alloxan-induced hyperglycemia, hypolipidic activity in experimental mouse model of hyperlipidemia [14], as well as protective effects on liver injuries in mice [15]. More recently, polysaccharide from A. subcrenata was demonstrated to induce proliferation of spleen lymphocyte in vitro [16]. However, no information is currently available on its anti-tumor activity either in vitro or in vivo. During the course of our extensive screening program on marine traditional Chinese medicines for in vitro anti-tumor activities, A. subcrenata was selected because of its widespread geographic distribution in China and its unique reputation in folklore medicine.

In our present study, purification and characterization of protein components of $A$. subcrenata were investigated. Their in vitro anti-tumor activity was also evaluated by examining cytotoxicity against seven human tumor cell lines.

\section{Materials and Methods}

\subsection{Materials}

DEAE Sepharose Fast Flow and Sephadex G-50 were obtained from Pharmacia Biotechnology. L-glutamide and 3-(4,5-dimethylthiazol-2-yl)-2,5-diphenyltetrazolium bromide (MTT) were purchased from Amresco Inc., Solon, Ohio, USA. Coomassie Brilliant Blue G-250 and Bovine Serum Albumin were obtained from Sino-American Biotechnology Co., USA. RPMI-1640 medium was purchased from GIBCO, USA and Cisplatin (cis-diamminedichloroplatinum, CDDP) from David Bull Laboratory. Fetal bovine serum (FBS) was provided by Hangzhou Sijiqing Corp, P.R. China. Benzylpenicillin sodium was obtained from Jiangxi Dongfeng Pharmaceutical Co., Ltd., P.R. China. Streptomycin sulfate was produced by North China Pharmaceutical Group Corporation. Molecular weight markers were obtained from Shanghai Puyi Biotechnology Co., Ltd., P.R. China. All other chemicals and reagents used were of analytical grade.

\subsection{Extraction of total proteins}

The visceral mass of $A$. subcrenata $(200 \mathrm{~g})$ was washed with $4{ }^{\circ} \mathrm{C}$ tap water three times, followed by washing with $4{ }^{\circ} \mathrm{C}$ distilled water three times. It was then homogenized with double volume of PBS 
(10 mM, pH 8.0) at $4{ }^{\circ} \mathrm{C}$ for $3 \mathrm{~min}$. After centrifugation $(16,000 \mathrm{~g}, 20 \mathrm{~min})$ at $4{ }^{\circ} \mathrm{C}$, the supernatant was collected and the crude extract obtained. The crude extract of $A$. subcrenata was fractionated by salting out with increasing concentrations of ammonium sulfate. Solid ammonium sulfate was slowly added to the above crude extract with gentle stirring, up to $35 \%$ saturation in $20 \mathrm{~min}$. After the crude extract was left at $4{ }^{\circ} \mathrm{C}$ with the ammonium sulfate under vortexing for another $40 \mathrm{~min}$ [17], the protein precipitate was collected by centrifugation $(16,000 \mathrm{~g}, 20 \mathrm{~min})$ at $4{ }^{\circ} \mathrm{C}$. The supernatant was transferred to another beaker, and solid ammonium sulfate was added to it up to $70 \%$ saturation. The mixture was treated as above. Likewise, another protein precipitate was obtained at $70 \%-100 \%$ saturation of ammonium sulfate. Each of the three protein pellets was suspended in $10 \mathrm{ml}$ of ice-cold PBS (10 mM, pH 8.0), and dialyzed against a large volume $(3 \mathrm{~L})$ of distilled water for $24 \mathrm{~h}$ at $4{ }^{\circ} \mathrm{C}$. Dialysis bags, with molecular weight cut-off (MWCO) of 1000 Da (Spectro/Pro 6: Spectrum-Laboratories, Inc.), were employed. During this process, the dialysate was changed three times to completely remove any residual ammonium sulfate.

\subsection{Purification of proteins}

Anion exchange chromatography (DEAE Sepharose Fast Flow): Fraction III obtained from the crude extract at 70\%-100\% saturation of ammonium sulfate was dialyzed against $10 \mathrm{mM}$ Tris- $\mathrm{HCl}, \mathrm{pH} 7.46$ for $5 \mathrm{~h}$ and the dialyzed solution was subsequently injected into a DEAE Sepharose Fast Flow column, which was pre-equilibrated with the aforementioned Tris-HCl buffer. The column was washed with the same buffer until the baseline returned to zero and remained stable. The column was then eluted with increasing concentration of $\mathrm{NaCl}$ prepared in $10 \mathrm{mM}$ Tris- $\mathrm{HCl}$ buffer, $\mathrm{pH} 7.46$ at $4{ }^{\circ} \mathrm{C}$. Aliquots of 5 $\mathrm{ml} /$ tube were collected at a flow rate of $1.2 \mathrm{ml} / \mathrm{min}$ and the absorbance was measured at $280 \mathrm{~nm}$. Seven $\mathrm{A}_{280 \mathrm{~nm}}$ peak fractions, named G-1, G-2, G-3, G-4, G-5, G-6 and G-7, were collected respectively.

Gel filtration chromatography (Sephadex G-50): The protein solution that passed through the anion exchange chromatographic column was concentrated by freeze-drying and loaded onto a Sephadex G-50 column that was pre-equilibrated with $10 \mathrm{mM}$ Tris-HCl buffer, $\mathrm{pH}$ 7.46. The flow rate was 0.65 $\mathrm{ml} / \mathrm{min}$, and the absorbance was monitored at $280 \mathrm{~nm}$. Three $\mathrm{A}_{280 \mathrm{~nm}}$ peak fractions, termed as G-4-1, G-4-2 and G-4-3, were obtained respectively.

\subsection{Cytotoxicity assay}

Cell lines and culture: Tumor cell lines used in this study included seven human cell lines, namely A549 (lung cancer cells), BEL-7404 (hepatocellular carcinoma cells), CNE (nasopharyngeal carcinoma cells), Hela (cervical carcinoma cells), PC-3 (prostatic carcinoma cells), HL-60 (leukemia cells) and KB (oral epithelial cancer cells). All of cell lines were provided by Shanghai Institutes for Biological Sciences, Chinese Academy of Sciences, and the cells were cultured in RPMI 1640 medium supplemented with heat-inactivated $10 \% \mathrm{FBS}, 0.2 \mathrm{mg} / \mathrm{L}$ L-glutamide, $1.0 \mathrm{mg} / \mathrm{mL} \mathrm{NaHCO} 3,100$ units $/ \mathrm{mL}$ penicillin, and 100 units $/ \mathrm{mL}$ streptomycin in a humidified incubator at $37{ }^{\circ} \mathrm{C}$ and $5 \% \mathrm{CO}_{2}$ atmosphere.

Evaluation of cytotoxicity: Cultured cells were taken during their exponential growth phase. Routinely, 
the cells were detached with $0.25 \%$ trypsin and cell suspension was made in the above medium. By trypan blue exclusion, cell viability greater than $95 \%$ was determined. One hundred microliters of cell suspensions containing $5 \times 10^{3}$ cells were seeded in each well of a 96-well microtiter plate and incubated at $37{ }^{\circ} \mathrm{C}$ in a humidified incubator with $5 \% \mathrm{CO}_{2}$. After $24 \mathrm{~h}$, the cells were treated with aseptic samples which were sterilized by passing through $0.22 \mu \mathrm{m}$ Millipore filter, and CDDP was used as the positive control. Untreated cells were used as negative control. Each plate was incubated for another $72 \mathrm{~h}$ at $37{ }^{\circ} \mathrm{C}$ in a humidified incubator with $5 \% \mathrm{CO}_{2}$. Cytotoxic activity was evaluated in vitro by MTT assay [18] and is expressed as $\mathrm{IC}_{50}$, i.e. the sample concentration able to inhibit cell growth by $50 \%$ compared with the untreated control. All experiments were carried out in triplicate, and data in the form of mean $\pm \mathrm{SD}$ are presented.

\subsection{Protein assay}

The protein content of total protein extract, fraction-I, fraction-II, fraction-III, G-6, G-4 and G-4-2 was determined by the method of Bradford [19] with bovine serum albumin as standard.

\subsection{Sodium dodecyl sulfate-polyacrylamide gel electrophoresis (SDS-PAGE)}

The Sodium dodecyl sulfate-polyacrylamide gel electrophoriesis (SDS-PAGE) analysis was performed with a mini-gel apparatus (Protean II. BioRAD, USA). There were two SDS- PAGE systems employed. The samples were analyzed by SDS-PAGE in Laemmli gel [20] with an acrylamide concentration of $5 \%$ for the stacking gel and $12 \%$ for the running gel, as well as in Tricine-SDS-PAGE [21] with an acrylamide concentration of $4 \%$ for the stacking gel, $10 \%$ for the space gel and $15.5 \%$ for the running gel. Five to thirty micrograms of protein per well was loaded on the gel. Protein bands were detected by the Coomassie blue staining method [22].

\subsection{Isoelectric focusing-polyacrylamide gel electrophoresis (IEF)}

Ampholyte (40\%, pH 3.5-10.0) was used to prepare IEF gel with acrylamide concentration of 5\%. The isoelectric focusing-polyacrylamide gel electrophoresis (IEF-PAGE) was carried out on BIO-RAD power PAC-300 and Mini-PROTEAN 3 cell provided by BIO-RADKWS at $150 \mathrm{~V}$ for 75 volt-hours (vh), then at $200 \mathrm{~V}$ for $500 \mathrm{vh}$. The IEF-PAGE gel unloaded samples was washed by double distilled water, and sliced into pieces of $0.5 \mathrm{~cm}$ in length from acidic terminal to basic terminal, then separately dipped into Eppendorf tubes containing $2.0 \mathrm{~mL}$ of $10 \mathrm{mM} \mathrm{KCl}$ for $30 \mathrm{~min}$. The $\mathrm{pH}$ value of the liquid around each slice was measured. The gel-loaded samples was fixed with $10 \%$ trichloroacetic acid for $30 \mathrm{~min}$, and rinsed thoroughly with destaining solution $(0.25 \% \mathrm{SDS}, 33 \%$ ethanol, and $10 \%$ acetic acid). Data were derived from calibration curve of isoelectric point with the length of gel as abscissa and $\mathrm{pH}$ value as ordinate.

\subsection{Reversed-phase high performance liquid chromatography (HPLC)}

HPLC analyses were performed on an Agilent series 1100 HPLC system fitted with a reversed-phase high performance liquid chromatography (RP-HPLC) cartridge, $4.6 \mathrm{~mm} \times 150 \mathrm{~mm}$ filled with ZORBAX ${ }^{\circledR}$ 300SB-C8, $5 \mu \mathrm{m}$ (Agilent). The solvent system was the following: solvent A: 
$0.1 \%(\mathrm{v} / \mathrm{v})$ trifluoroacetic acid (TFA) in $\mathrm{H}_{2} \mathrm{O}$; solvent B: 0.1\% (v/v) TFA in $\mathrm{H}_{2} \mathrm{O}$ : acetonitrile 1: $4(\mathrm{v} / \mathrm{v})$ [23-28]. Gradient elution from $50 \%$ to $70 \%$ of solvent B in $35 \mathrm{~min}$; flow rate: $1 \mathrm{~mL} / \mathrm{min}$; detection wavelength: $280 \mathrm{~nm}$; column temperature $30^{\circ} \mathrm{C}$.

\subsection{Analysis of saccharides}

The concentrations of methyl glycoproteins and glycoproteins were accurately determined by using calibration curves composed of the appropriate monosaccharide(s) obtained with a modified version of the colorimetric phenol-sulfuric acid method [29-31]. $200 \mu \mathrm{g} / \mathrm{mL}$ glucose solution was served as standard. The absorbance at $490 \mathrm{~nm}$ was used to determine the amount of carbohydrate in the sample.

\subsection{Analysis of amino acid components}

The content of amino acids was analyzed by an amino acid automatic analyzer (Hitachi 835-50) fitted with ion exchange resin (Hitachi 2619). Appropriate amount of purified and freeze-dried samples were weighed and applied into hydrolysis tube. $6 \mathrm{~mol} / \mathrm{L} \mathrm{HCl}$ was added and the vessel was sealed and evacuated. Hydrolysis was allowed to proceed at $110^{\circ} \mathrm{C}$ for $24 \mathrm{~h}$. The samples were then dried, dissolved in $0.02 \mathrm{~N} \mathrm{HCl}$, and centrifuged at 10,000 rpm for 15 mins. The amino acid compositions were then obtained by automatic analysis algorithm of Hitachi L 835-50. The analysis conditions were as follows: flow rate: $0.225 \mathrm{~mL} / \mathrm{min}$, column temperature: $53^{\circ} \mathrm{C}$, column pressure: $80-130 \mathrm{~kg} / \mathrm{cm}^{2}$, analysis time: $74 \mathrm{~min}$.

\section{Results and Discussion}

\subsection{In vitro bioactivity-guided fractionation}

Cytotoxicity is one of the chemotherapeutic hallmarks of anti-tumor activity [32]. MTT assay, a well-established in vitro model for cytotoxicity against cancer cell lines, was used as one of conventional methods for the screening of compounds with potential anti-tumor properties [33]. Since it is well known that different cell lines can exhibit different sensitivities to a cytotoxic compound, seven tumor cell lines with different origins, morphologies, and tumorigenicities were employed.

To screen natural products with in vitro anti-tumor activity, the total proteins extract of $A$. subcrenata was subjected to cytotoxicity assay. The results showed that the total proteins extract of $A$. subcrenata suppressed the proliferation of Hela, HL-60, CNE and A549 cells, with $\mathrm{IC}_{50}$ values of 35.6 $\mu \mathrm{g} / \mathrm{mL}, 106.0 \mu \mathrm{g} / \mathrm{mL}, 145.9 \mu \mathrm{g} / \mathrm{mL}$ and $306.1 \mu \mathrm{g} / \mathrm{mL}$, respectively (Table 1).

In order to identify cytotoxic components, the total proteins extract of $A$. subcrenata was fractionated by salting-out at increasing saturation levels of ammonium sulfate. The Fraction-I, Fraction-II, and Fraction-III were obtained at the ammonium sulfate saturation of $0-35 \%, 35-70 \%$ and $70-100 \%$, and their percentage yield was $7.1 \%, 41.4 \%$ and $25.4 \%$, respectively. In the evaluation of cytotoxicity of three fractions, the fraction-III exhibited the significant inhibition on the proliferation of Hela, HL-60 and KB cells with $\mathrm{IC}_{50}$ values of $6.7 \mu \mathrm{g} / \mathrm{mL}, 14.7 \mu \mathrm{g} / \mathrm{mL}$ and $76.5 \mu \mathrm{g} / \mathrm{mL}$, respectively (Table 1). The results suggested that the fraction-III warranted further purification in order to unveil the active components of $A$. subcrenata. 
Table 1. Cytotoxicity of protein samples against seven human tumor cell lines $\left(\mathrm{IC}_{50}\right.$ $\mu \mathrm{g} / \mathrm{mL} \pm \mathrm{SD}, \mathrm{n}=3)$.

\begin{tabular}{llllllll}
\hline \multirow{2}{*}{ Samples } & \multicolumn{7}{c}{ Cell lines } \\
& A549 & Hela & PC-3 & HL-60 & KB & BEL-7404 & CNE \\
\hline Total & $306.1 \pm 28.4$ & $35.6 \pm 2.9$ & $>500$ & $106.0 \pm 14.6$ & $>500$ & $>500$ & $145.9 \pm 25.9$ \\
protein & & & & & & & \\
extract & & & & & & & \\
Fraction-I & $>500$ & $>500$ & $>500$ & $>500$ & $>500$ & $>500$ & $>500$ \\
Fraction-II & $>500$ & $>500$ & $>500$ & $>500$ & $>500$ & $>500$ & $>500$ \\
Fraction-III & $351.7 \pm 40.6$ & $6.7 \pm 0.8$ & $>500$ & $14.7 \pm 1.7$ & $76.5 \pm 4.9$ & $>500$ & $>500$ \\
G-6 & $>500$ & $>500$ & $>500$ & $123.2 \pm 11.3$ & $>500$ & $>500$ & $>500$ \\
G-4 & $>500$ & $38.2 \pm 2.7$ & $>500$ & $67.8 \pm 7.1$ & $78.1 \pm 9.0$ & $>500$ & $>500$ \\
G-4-2 & $>500$ & $22.9 \pm 2.4$ & $>500$ & $46.1 \pm 3.5$ & $57.7 \pm 7.2$ & $>500$ & $>500$ \\
\hline
\end{tabular}

Fraction-I : $\left(0-35 \%\right.$ saturated $\left.\left(\mathrm{NH}_{4}\right)_{2} \mathrm{SO}_{4}\right)$; Fraction-II: $\left(35-70 \%\right.$ saturated $\left.\left(\mathrm{NH}_{4}\right)_{2} \mathrm{SO}_{4}\right)$; Fraction-III:

$\left(70-100 \%\right.$ saturated $\left.\left(\mathrm{NH}_{4}\right)_{2} \mathrm{SO}_{4}\right)$

\subsection{Purification of cytotoxic proteins from A. subcrenata}

Fraction-III was subjected to ion exchange chromatography for purification. Seven $\mathrm{A}_{280 \mathrm{~nm}}$ peak fractions were obtained through elution with increasing concentrations of $\mathrm{NaCl}$ containing Tris- $\mathrm{HCl}$ (10 mM, pH 7.46) on DEAE Sepharose Fast Flow column (Figure 1).

The results of cytotoxicity experiments showed that fraction G-6 had the ability to only suppress the proliferation of HL-60 cells ( $\mathrm{IC}_{50}=123.2 \mu \mathrm{g} / \mathrm{mL}$ ), whereas fraction G-4 appeared to possess inhibitory activity not only against HL-60 cells $\left(\mathrm{IC}_{50}=67.8 \mu \mathrm{g} / \mathrm{mL}\right)$, but also against Hela cells $\left(\mathrm{IC}_{50}=38.2\right.$ $\mu \mathrm{g} / \mathrm{ml})$ and $\mathrm{KB}$ cells $\left(\mathrm{IC}_{50}=78.1 \mu \mathrm{g} / \mathrm{mL}\right)$.

Furthermore, fraction G-4 was rechromatographed on a Sephadex G-50 column (Figure 2). The other subfractions were not found to be active against these seven human tumor cell lines.

Three $\mathrm{A}_{280 \mathrm{~nm}}$ peak fractions were collected and evaluated for their cytotoxic activities. Among the fractions, the $\mathrm{IC}_{50}$ values of fraction G-4-2 towards Hela, HL-60 and KB cell lines were measured to be $22.9 \mu \mathrm{g} / \mathrm{mL}, 46.1 \mu \mathrm{g} / \mathrm{ml}$, and $57.7 \mu \mathrm{g} / \mathrm{mL}$, respectively.

Fraction-III showed cytotoxic activity against A549, but none of its subfractions presented that activity. There are probably synergistic and additive effects among subfractions in the fractionation of natural marine medicines. These effects weaken as further isolation and purification proceeds. This is corroborated by the observation that each subfraction of fraction-III exhibits lower activity towards A549 than fraction-III. In the same way fraction-III presented a lower $\mathrm{IC}_{50}$ than some of its subfractions (i.e. against Hela and HL-60 lines), and purified subfractions showed lower activities against Hela and HL-60 lines. 
Figure 1. The curve of elution in DEAE Sepharose Fast Flow chromatography. Column specification: $1.6 \times 30 \mathrm{~cm}$; Equilibrate liquid: buffer C (Tris- $\mathrm{HCl}, \mathrm{pH} 7.46,10$ $\mathrm{mM}$ ); Sample: Fraction-III; Detection wavelength: UV $280 \mathrm{~nm}$; Flow rate: $1.2 \mathrm{~mL} / \mathrm{min}$; Collection rate: $5 \mathrm{~mL} /$ tube.

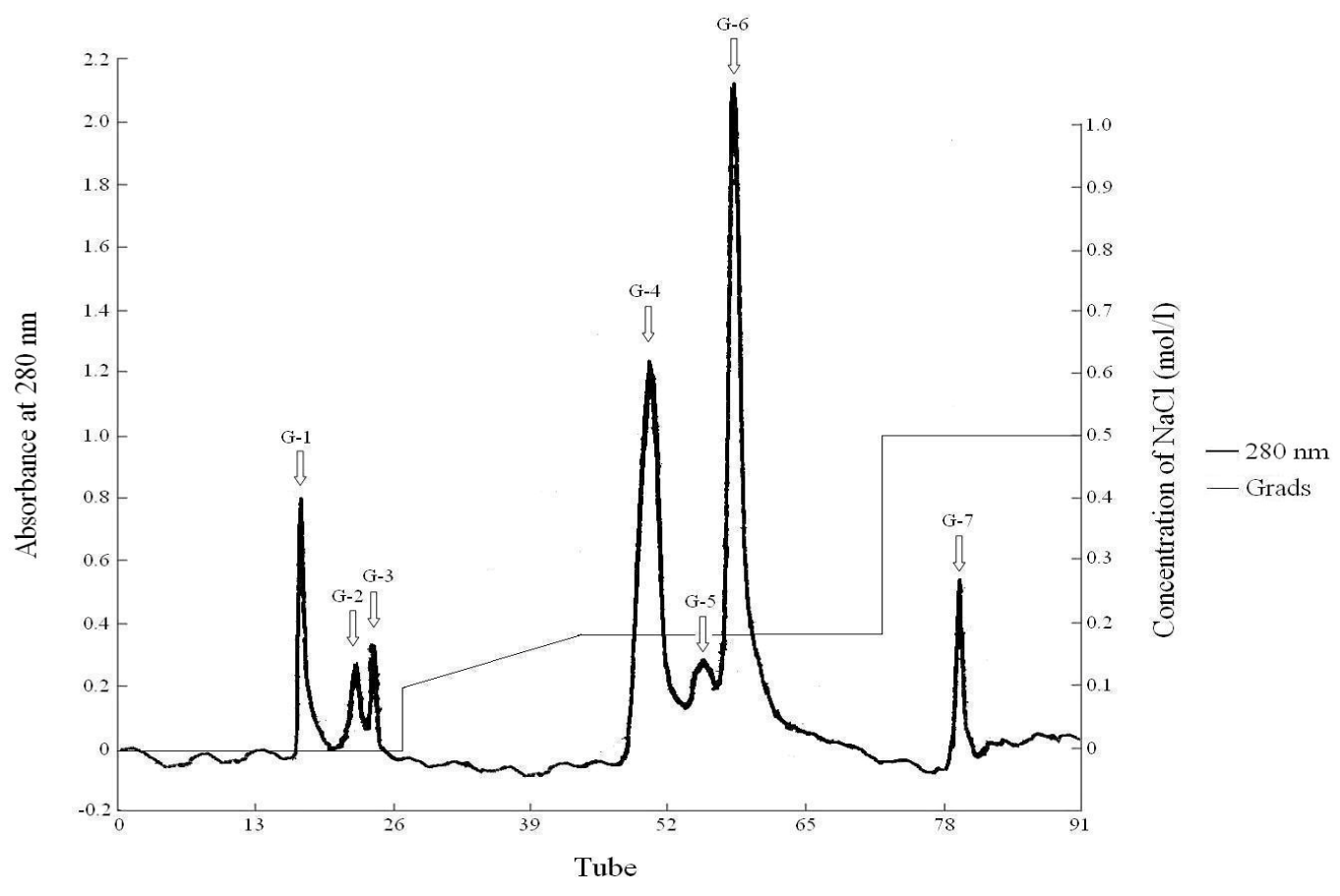

Figure 2. The curve of G-4 separated by Sephadex G-50 chromatography. Column specification: $1.0 \times 100 \mathrm{~cm}$; Equilibrate liquid: buffer C (Tris-HCl, pH 7.46, $10 \mathrm{mM}$ ); Sample: G-4; Detection wavelength: UV $280 \mathrm{~nm}$; Flow rate: $0.65 \mathrm{~mL} / \mathrm{min}$; Collection rate: $3 \mathrm{~mL} /$ tube.

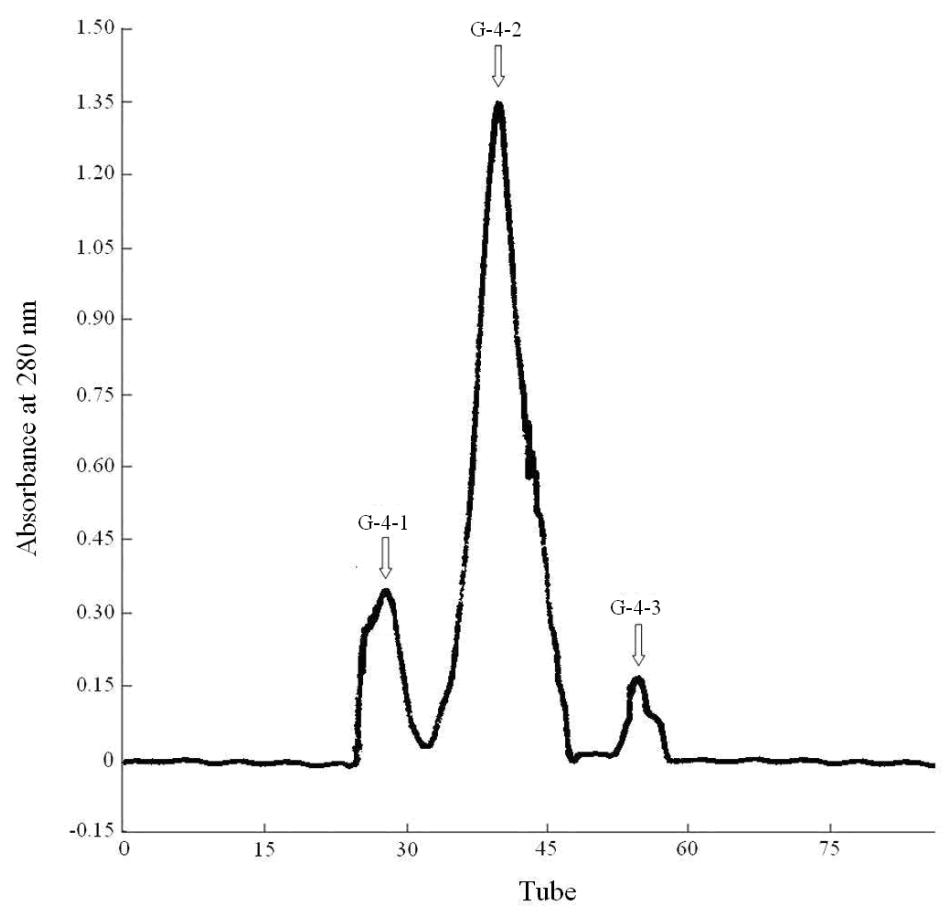




\subsection{Characterization of purified proteins}

To estimate the molecular weight of G-6, Tricine-glycerol SDS-PAGE was employed with molecular weight marker ranging from $3.3 \mathrm{kDa}$ to $20.1 \mathrm{kDa}$ as standard. Similarly, SDS-PAGE was utilized to estimate the molecular weight of G-4-2, with molecular weight marker ranging from 14.4 $\mathrm{kDa}$ to $97.4 \mathrm{kDa}$ as standard (Figure 3).

Figure 3. The SDS-PAGE of G-6 and G-4-2. (A) Tricine-glycerol SDS-PAGE of G-6. lane a: molecular weight marker (range from $3.3 \mathrm{kDa}$ to $20.1 \mathrm{kDa}$ ); lane b: G-6. (B) SDS-PAGE of G-4-2. lane a: G-4-2; lane b: molecular weight marker (range from 14.4 $\mathrm{kDa}$ to $97.4 \mathrm{kDa})$

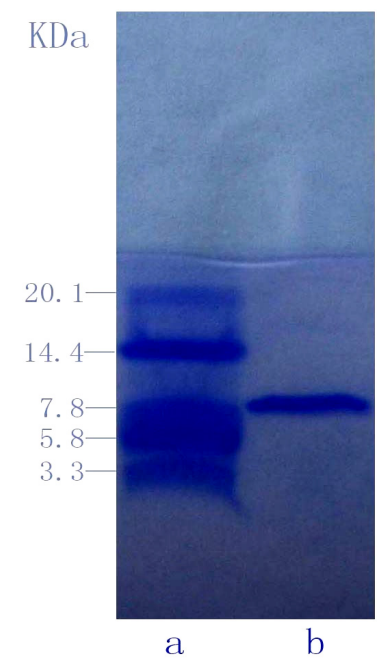

(A)

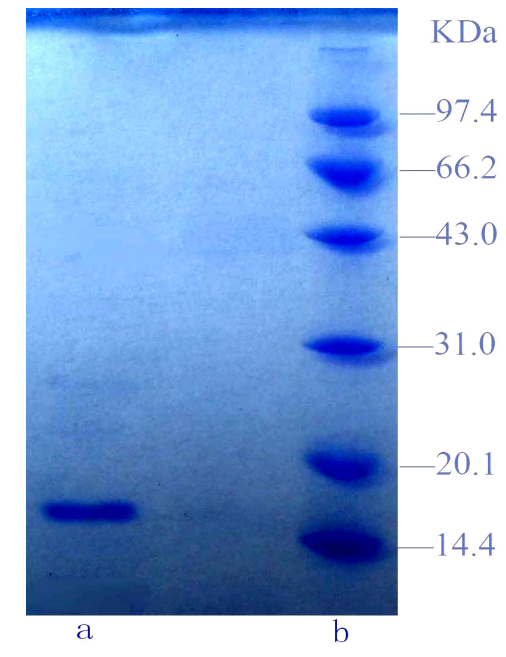

(B)

According to calibration curves, the molecular weights of G-6 and G-4-2 were $8.2 \mathrm{kDa}$ and 16.0 $\mathrm{kDa}$. And the isoelectric points (pI) of G-6 and G-4-2 were 6.6 and 6.1, respectively. The two proteins were both single bands in SDS-PAGE and IEF-PAGE. Furthermore, the results of RP-HPLC (Figure 4 and Figure 5) indicated the purity of G-6 and G-4-2 was $97.6 \%$ and $96.8 \%$, respectively.

Figure 4. RP-HPLC of G-6.

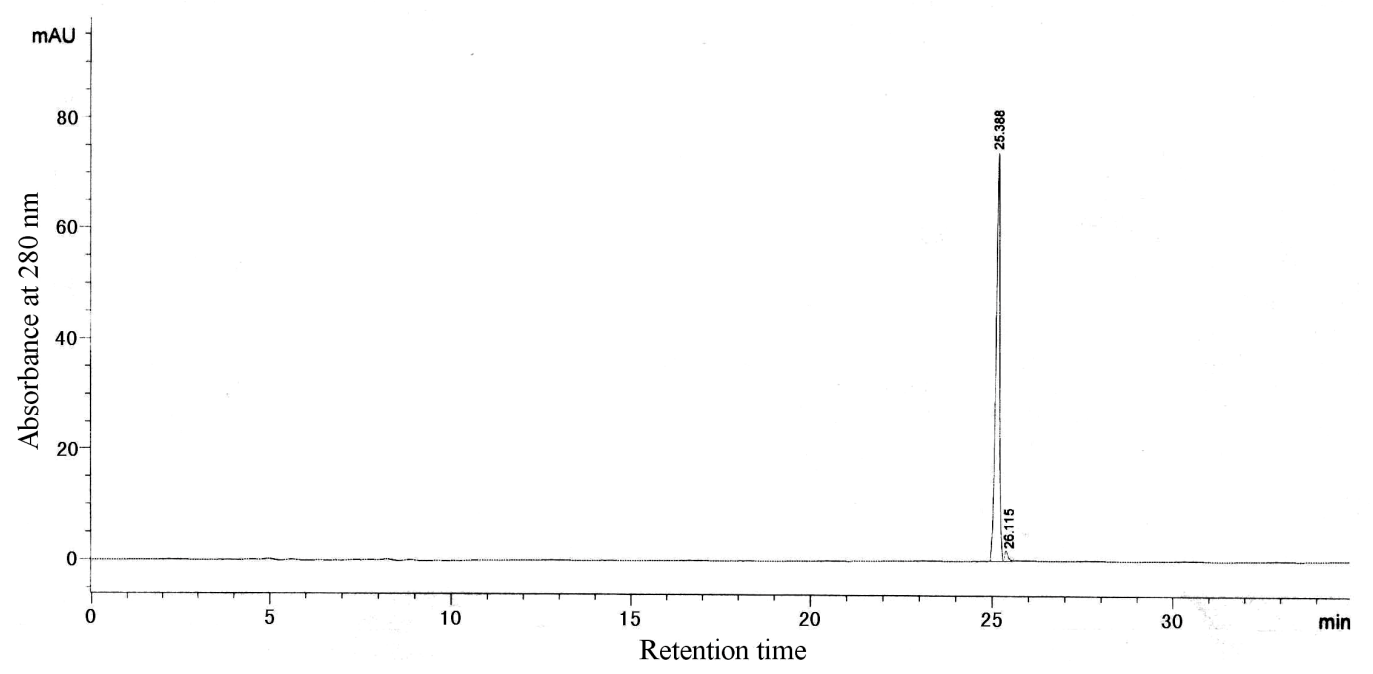


Figure 5. RP-HPLC of G-4-2.

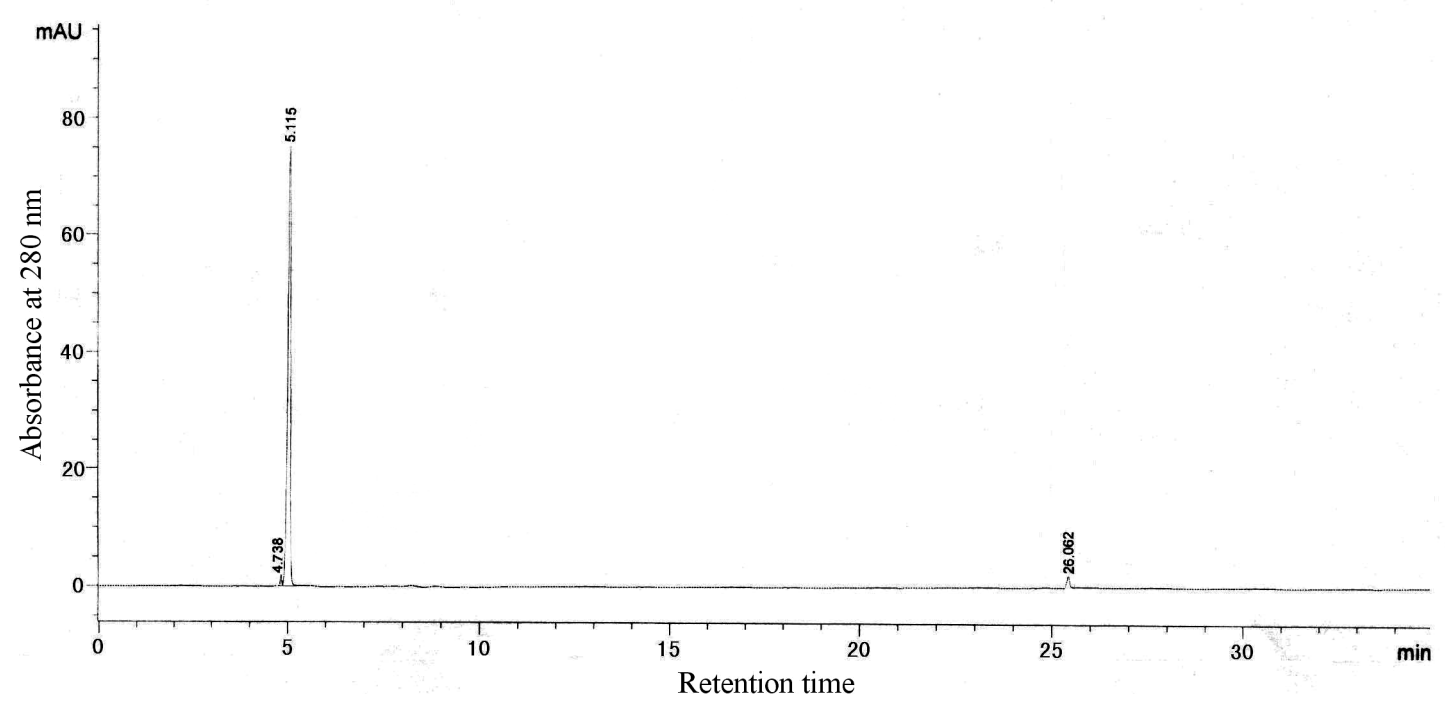

According to modified version of the colorimetric phenol-sulfuric acid method, G-6 may be a glycoprotein but not G-4-2. The amino acid compositions of G-6 and G-4-2 were shown in Table 2 and Table 3.

Table 2. The amino acid compositions of G-6.

\begin{tabular}{ccc}
\hline $\begin{array}{c}\text { Amino } \\
\text { acid }\end{array}$ & $\begin{array}{c}\text { The content of amino acid } \\
(\mathbf{m g} / \mathbf{m l})\end{array}$ & $\begin{array}{c}\text { The mass percentage of } \\
\text { amino acid (\%) }\end{array}$ \\
\hline Asp & 0.0352 & 11.72 \\
Thr & 0.0160 & 5.33 \\
Ser & 0.0000 & 0.00 \\
Glu & 0.0426 & 14.18 \\
Gly & 0.0102 & 3.39 \\
Ala & 0.0178 & 5.93 \\
Cys & 0.0483 & 16.08 \\
Val & 0.0123 & 4.09 \\
Met & 0.0056 & 1.86 \\
Ile & 0.0079 & 2.63 \\
Leu & 0.0142 & 4.73 \\
Tyr & 0.0157 & 5.23 \\
Phe & 0.0039 & 1.30 \\
Lys & 0.0251 & 8.36 \\
His & 0.0214 & 7.12 \\
Arg & 0.0197 & 6.56 \\
Pro & 0.0000 & 0.00 \\
\hline
\end{tabular}


Table 3. The amino acid compositions of G-4-2.

\begin{tabular}{ccc}
\hline $\begin{array}{c}\text { Amino } \\
\text { acid }\end{array}$ & $\begin{array}{c}\text { The content of amino acid } \\
(\mathbf{m g} / \mathbf{m l})\end{array}$ & $\begin{array}{c}\text { The mass percentage of } \\
\text { amino acid }(\%)\end{array}$ \\
\hline Asp & 0.2563 & 15.64 \\
Thr & 0.1005 & 6.13 \\
Ser & 0.0633 & 3.86 \\
Glu & 0.2364 & 14.43 \\
Gly & 0.0741 & 4.52 \\
Ala & 0.0747 & 4.56 \\
Cys & 0.0440 & 2.69 \\
Val & 0.0657 & 4.01 \\
Met & 0.0613 & 3.74 \\
Ile & 0.1035 & 6.32 \\
Leu & 0.0412 & 2.51 \\
Tyr & 0.0758 & 4.63 \\
Phe & 0.1056 & 6.45 \\
Lys & 0.2100 & 12.82 \\
His & 0.0335 & 2.04 \\
Arg & 0.0426 & 2.60 \\
Pro & 0.0000 & 0.00 \\
\hline
\end{tabular}

\section{Conclusions}

Based upon the results of the in vitro cytotoxicity assay, two proteins from $A$. subcrenata underwent the bioactivity-guided fractionation and purification. Important characteristics of proteins G- 6 and G-4-2 were identified, showing their molecular weights to be $8.2 \mathrm{kDa}$ and $16.0 \mathrm{kDa}$ and their isoelectric points to be 6.6 and 6.1, respectively. G-6, but not G-4-2, is shown to be a glycopeptide.

Additionally, our present study reveals for the first time the in vitro anti-tumor activity of $A$. subcrenata, and the significance of this finding is deepened by the knowledge that in the past, many pharmaceutical agents were discovered by screening natural products from plants, animals, marine organisms and microorganisms [34]. A. subcrenata is a member of mollusks constituting a large marine animal family. Some mollusks such as oyster have been found to contain compounds with anti-tumor activities. The extract of oyster has significant in vitro cytotoxic effect on human A549 cell lines [35], and in vivo anti-tumor activity against murine hepatic cancer [36]. In addition, there has been much interest in the research on bioactive peptides from marine sources. For example, protein from Chlamys farreri (PCF), a species of Chinese scallop, was recently shown to have potential antioxidant activity and protective effect against ultraviolet (UV) irradiation [37]. Similarly, a group in Korea reported that methanolic extracts from seaweed Plocamium telfairiae (PTE) exhibited a cytotoxic effect against HT-29 human colon carcinoma cells [38].

The combination of chemical and biological approaches provides scientists with a valuable tool to efficiently investigate a wide array of natural products. As a whole, the results in our paper suggest that 
A. subcrenata is a promising resource in the development of novel drugs for its anti-tumor potential. Further studies on mechanism of bioactive proteins, their structure-function relationships and the in vivo anti-tumor effects of $A$. subcrenata are currently underway.

\section{Acknowledgments}

This research work was financially supported from the Key Subjects of Scientific and Technological Foundation of Guangdong (Grants No. 2004A30505003) and the Key Subjects of Scientific and Technological Foundation of Guangzhou (Grants No. 2005Z2-E4031). The authors thank Dongbo Yu of University of Texas Southwestern Medical Center, USA, for proof-reading our manuscript.

\section{References}

1. Belarbi, E.H.; Contreras, Gómez A.; Chisti, Y.; García, Camacho F.; Molina, Grima E. Producing drugs from marine sponges. Biotechnol. Adv. 2003, 21, 585-598.

2. Schwartsmann, G.; da Rocha, A.B.; Berlinck, R.; Jimeno, J. Marine organisms as a source of new anticancer agents. Lancet Oncol. 2001, 2, 221-225.

3. Mayer, A.M.S. Marine pharmacology in 1998: antitumor and cytotoxic compounds. Pharmacologist 1999, 41, 159-164.

4. Mayer, A.M.S.; Lehmann, V.K.B. Marine pharmacology in 1999: antitumor and cytotoxic compounds. Anticancer Res 2001, 21, 2489-2500.

5. Mayer, A.M.S.; Gustafson, K.R. Marine pharmacology in 2000: antitumor and cytotoxic compounds. Int. J. Cancer 2003, 105, 291-299.

6. Mayer, A.M.S.; Gustafson, K.R. Marine pharmacology in 2001-2: antitumour and cytotoxic compounds. Eur. J. Cancer 2004, 40, 2676-2704.

7. Mayer, A.M.S.; Gustafson, K.R. Marine pharmacology in 2003-2004: anti-tumour and cytotoxic compounds. Eur. J. Cancer 2006, 42, 2241-2270.

8. Zhang, Y.P.; Xu, F.; Wang, M. Progress on Marine Anticancer Drugs in R\&D. Prog. Pharmaceut. Sci. 2006, 30, 433-442.

9. Suárez, Y.; González, L.; Cuadrado, A.; Berciano, M.; Lafarga, M.; Muñoz, A. Kahalalide F. A new marine-derived compound, induces oncosis in human prostate and breast cancer cells. Mol. Cancer Ther. 2003, 2, 863-872.

10. Riely, G.J.; Gadgeel, S.; Rothman, I.; Saidman, B.; Sabbath, K.; Feit, K.; Kris, M.G..; Rizvi, N.A. A phase 2 study of TZT-1027, administered weekly to patients with advanced non-small cell lung cancer following treatment with platinum-based chemotherapy. Lung Cancer 2007, 55, 181-185.

11. Kerbrat, P.; Dieras, V.; Pavlidis, N.; Ravaud, A.; Wanders, J. Fumoleau, P. and For the EORTC Early Clinical Studies Group/New Drug Development Office. Phase II study of LU 103793 (dolastatin analogue) in patients with metastatic breast cancer. Eur. J. Cancer 2003, 39, 317-320.

12. Guo, X.S.; Li, Y. Marine Chinese Traditional Medicines; Sciences Press: Beijing, P.R. China, 2003; pp. 138-141. 
13. Li, Q.; Li, T.M.; Wang, X.Q.; Huang, Q.; Wu, W.J. Biochemical properties analysis of Arca subcrenata extractive. Pharm. Biotechnol. 1998, 5, 245-247.

14. Dou, C.G.; Yan, Y.Q.; Zhang, Z. Experimental studies on hypoglycemia and hypolipid effects of hydrolysate of Arca subcrenata. Chin. J. Mar. Drug. 1996, 15(1), 13-15.

15. Dou, C.G.; Yan, Y.Q.; Zhang, Z. The protective action of hydrolysate of Arca Subcrenata on liver injuries in mice. Chin. J. Mar. Drug 1996, 15(3), 17-19.

16. He, Y.M.; Chen, Y.X.; Liu, C.H.; Xi, T.; Shen, Z.L.; Yao, Q.S. Isolation, purification and immunological activity assay of polysaccharide from Arca subcrenata Lischke. Chin. J. Mar. Drug 2007, 26(2), 23-26.

17. Murphy, E.J.; Edmondson, R.D.; Russell, D.H.; Colles, S.; Schroeder, F. Isolation and characterization of two distinct forms of livers fatty acid binding protein from the rat. Biochim. Biophys. Acta 1999, 1436, 413-425.

18. Fatope, M.O.; Zeng, L.; Ohayaga, J.E.; Shi, G.; Mclaughlin, J.L. Selectively cytotoxic diterpenes from Euphorbia poisonii. J. Med. Chem. 1996, 39, 1005-1008.

19. Bradford, M.M. A rapid and sensitive method for the quantitation of microgram quantities of protein utilizing the principle of protein-dye binding. Anal. Biochem. 1976, 72, 248-254.

20. Laemmli, U.K. Cleavage of structural proteins during the assembly of the head of bacteriophage T4. Nature 1970, 227, 680-685.

21. Schägger, H.; von Jagow, G. Tricine-sodium dodecyl sulfate-polyacrylamide gel electrophoresis for the separation of proteins in the range from 1 to $100 \mathrm{kDa}$. Anal. Biochem. 1987, 166, 368-379.

22. Stephano, J.L.; Gould, M.; Rojas-Galicia, L. Advantages of picrate fixation for staining polyproteins in polyacrylamide gels. Anal. Biochem. 1986, 152, 308-313.

23. Thompson, P.E.; Hearn, M.T. A simple and inexpensive sample-handling method for the semi-preparative RP-HPLC of polyproteins and non-polar peptide derivatives: pre-adsorption of sample. J. Biochem. Biophys. Methods 1995, 30, 153-161.

24. Lee, R.P.; Doughty, S.W.; Ashman, K.; Walker, J. Purification of hydrophobic integral membrane proteins from Mycoplasma hyopneumoniae by reversed-phase high-performance liquid chromatography. J. Chromatogr. A 1996, 737, 273-279.

25. Fujinari, E.M.; Manes, J.D.; Bizanek, R. Peptide content determination of crude synthetic proteins by reversed-phase liquid chromatography and nitrogen-specific detection with a chemiluminescent nitrogen detector. J. Chromatogr. A 1996, 743, 85-89.

26. Venkateshwaran, T.G.; Stewart, J.T.; de Haseth, J.A.; Bartlett, M.G. Solution conformation of model polyproteins with the use of particle beam LC/FT-IR spectrometry and electrospray mass spectrometry. J. Pharm. Biomed. Anal 1999, 19, 709-723.

27. Zolla, L.; Bianchetti, M. High-performance liquid chromatography coupled on-line with electrospray ionization mass spectrometry for the simultaneous separation and identification of the Synechocystis PCC 6803 phycobilisome proteins. J. Chromatogr. A 2001, 912, 269-279.

28. Pavli, V.; Kmetec, V. Optimization of HPLC method for stability testing of bacitracin. $J$ Pharm Biomed. Anal. 2001, 24, 977-982. 
29. Saha, S.K.; Brewer, E.F. Determination of the concentration of oligosaccharides: complex type carbohydrates and glycoproteins using the phenol-sulfric acid method. Carbohydr. Res. 1994, $254,157-167$.

30. Dong, Q.; Zheng, L.Y.; Fang, J.Y. Modified phenol-sulfuric acid method for determination of the content of oligosaccharides and polysaccharides. Chin. Pharm. J. 1996, 31, 550-553.

31. Bao, X.F.; Fang, J.N. Studies on difference between sporoderm-broken and nonbroken spores of gan derma lucidum (leyss. Ex fr.) karst. by polysaccharide analysis. China J. Chin. Mat. Med. 2001, 26, 326-328.

32. Suffness, M.; Pezzuto, J.M. Methods in Plant Biochemistry; Academic Press: New York; NY, USA; Volume 1, 1991.

33. Xu, S.Y.; Bian, R.L.; Chen, X. Methodology of Pharmacological Experiment, $3^{\text {rd }}$ Ed.; People's Medical Publishing House: Beijing, P.R. China, 1991.

34. da Rocha, A.B.; Lopes, R.M.; Schwartsmann, G. Natural products in anticancer therapy. Curr. Opin. Pharmacol. 2001, 1, 364-369.

35. Huang, D.C. ; Li, Q.F. ; Li, P. ; Li, X.Q. ; Song, Y.Z. Effects of oyster low molecular weight bioactive substance on the human lung adenocarcinoma A549 cells. J. Xiamen Univ. (Nat. Sci.) 2002, 41, 614-617.

36. Wang, Y.; Ma, A.L.; Zhang, H.Z.; Xue, B.H.; Zhao, Z.J.; Fu, F.H.; Zhou, G.Y. Experimental studies on the antitumor effect of oyster extract. Chin. J. Mar. Drug 1997, 16, 18-22.

37. Li, B.-H.; Zhou, Y.-B.; Guo, S.-B.; Wang, C.-B. Protein from Chlamys farreri inhibits UVB-induced HaCaT cells apoptosis via inhibition CD95 pathway and reactive oxygen species. Free Rad. Res. 2007, 41, 1224-1232.

38. Kim, J,Y.; Yoon, M.Y.; Cha, M.R.; Hwang, J.H.; Park, E.; Choi, S.U.; Park, H.-R.; Hwang, Y.-I. Methanolic extracts of Plocamium telfairiae induce cytotoxicity and caspase-dependent apoptosis in HT-29 human colon carcinoma cells. J. Med. Food 2007, 10, 587-593.

(C) 2008 by the authors; licensee Molecular Diversity Preservation International, Basel, Switzerland. This article is an open-access article distributed under the terms and conditions of the Creative Commons Attribution license (http://creativecommons.org/licenses/by/3.0/). 